\title{
Impact of Inter-Row Spacing on Yield and Yield Components of several Annual Medics Species
}

\author{
Mahnaz BAGHERI, Seyed Ali Mohammad MODARRES SANAVY, Aria DOLATABADIAN
}

Tarbiat Modares University, Faculty of Agriculture,Agronomy Department, Tehran, Iran; modaresa@modares.ac.ir

\begin{abstract}
A field study was conducted in Faculty of Agriculture, Tarbiat Modares University, Tehran, Iran to evaluate the effects of three within-row spacing treatments $(20,30$ and $40 \mathrm{~cm}$ ) on forage and seed production of five species of annual medics (Medicago scutellata cv. 'Sava'; M. littoralis cv. 'Herald'; M. polymorpha cv. 'Santiago'; M. minima cv. 'Orion' and M. truncatula cv. 'Mogul'). The experiment was carried out in Faculty of Agriculture, Tarbiat Modares University, Tehran, Iran. The results of the experiment indicated that $M$. polymorpha had the highest forage yield out of the highest plant population. Latter with average $443.09 \mathrm{Kg} \mathrm{ha}^{-1}$ and $M$. scutellata with average $409.99 \mathrm{Kg} \mathrm{ha}^{-1}$ produced the highest seed yield. Also, the last species with $1306.78 \mathrm{Kg} \mathrm{ha}^{-1}$ had the highest pod yields. The highest seed yield and pod yield were produced at $20 \mathrm{~cm}$ within-row spacing because there were not adequate plants for maximum seed and pod yields in 30 and $40 \mathrm{~cm}$ within-row spacing. The tested plant densities did not affect on seeds number per pod, 1000 seeds weight and seeds to burr pod weight ratio. The $M$. truncatula and $M$. minima have the highest seeds number per pod. In addition, $M$. scutellata had the highest 1000 seeds weight with an average of $12.57 \mathrm{~g}$. The highest seeds to burr pod ratio was observed in $M$. polymorpha. The most pod numbers were obtained in 20 and $30 \mathrm{~cm}$ within-row spacing and $M$. polymorpha while, the least pod numbers was observed in M. scutellata. Plant densities did not affect on pod numbers of the mentioned species. The highest dry forage yield was produced in $20 \mathrm{~cm}$ within-row spacing. Among the tested tested species, $M$. truncatula had the highest forage yield with average $870.07 \mathrm{Kg}^{-1}$. This experiment indicated that there is possibility for seed and forage production of tested annual medics in the mentioned zone with the considering suitable plant densities.
\end{abstract}

Keywords: annual medics, forage, row spacing, yield, yield components

\section{Introduction}

Annual medics are important annual pasture legumes in southern Australia where they provide strains and possible preference of strains for forage for livestock, improve soil fertility, and enhance subsequent crop yield (Crawford et al., 1989). Medics increase pastures soil organic matter, enhance soil water retention and water availability, and improve soil nitrogen status due to symbiotic $\mathrm{N}_{2}$ fixation (Puckridge and French, 1983). Annual medics are used as winter annuals for livestock feed, for soil erosion control, and for supplying nitrogen to the soil (Clarkson et al., 1987; Lloyd and Hilder, 1985). If planted in spring in a northern temperate climate, they can be grown as summer annuals. The medics are fast growing and true annuals while most of them will complete their life cycle in 65 to 100 days. Medics appear to best adapted to soil with a $\mathrm{pH}$ of six and above, however, some species are more tolerant to low $\mathrm{pH}$ soil such as $M$. murex. The medics are for the most part restricted to Mediterranean climates with winter rain and long, hot, dry, summers. Annual medics are grown in medium rainfall zones $(250-500 \mathrm{~mm}$ annual rainfall). In general annual medics are native to the Mediterranean region (Iran, Syria), but are found in all major agricultural regions of the world. The most widespread species of annual medics are M. polymorpha and M. mini- ma (Crawford et al., 1989). The Australian species were selected for the mild to cool winter environment prevailing in the Mediterranean austral environment where frost remained exceptional (Gintzburger, 1994). Annual legumes may benefit farmers in that they can provide high-protein animal feed and fix atmospheric $\mathrm{N}_{2}$ in the soil for the next crop. They are capable of fixing up to $250 \mathrm{~kg} \mathrm{ha}^{-1}$ nitrogen (Zhu et al., 1996). It has believed that annual medics were based ley-farming system. Developing this farming system for this region relies on the inclusion of an annual medic pasture that is effective in producing increased levels of high quality forage over a summer growing season. Additionally, seed production and, therefore, seed bank establishment for regeneration are also linked to the level of dry matter produced (Puckridge and French, 1983). The genus Medicago contains 83 species growing predominately around the Mediterranean basin. Many factors including environment, genotype, and agronomic techniques, influence alfalfa seed yield and seed quality (Dordas, 2006). One of the major constraints of annual medic production is dearth of information on the plant density. Plant density is an important factor, which initially determines the leaf area and dry matter production (Spedding, 1971). The success of a pasture is depend to agronomic managing during the early growing season such as controlled grazing and suitable plant density application. Thus, it is impor- 
tant to determine the appropriate agronomic factors that optimize both forage and seed yield. Sheaffer et al. (2001) tested new forage varieties of soybean at two row distances and observed significantly higher yields in narrow-row culture. Hintz et al. (1992) using grain species, also reported that narrow row distance produced higher forage yield. In addition, plant density and row distance in annual medic is a significant factor for determining forage yield. Cazzato et al. (2000) investigated the effect of the row distances of 20, 40 and $60 \mathrm{~cm}$ on the seed yield of Palermo clover (Trifolium squarrosum L.) and crimson clover (Trifolium incarnatum L.). They found that seed yields obtained from $20 \mathrm{~cm}$ row distance were highest for both species and increasing the row spacing decreased the seed yield of crimson clover. Pacucci et al. (1999) reported that the highest vetch (Vicia sativa L.) seed yield was in 40-50 cm row spacing. Since plant density has such an importance and influence the productivity of medic pasture, it is necessary to include this factor in management experiments.

This field research was carried out to provide basic information on within-row plant density response from five species of annual medic and determine the optimum within-row spacing for successful forage and seed production of these medics. Our specific objectives were (i) comparison among five annual medic species (ii) investigation effect of within-row plant density on forage and seed production of five species of annual medics. Our hypothesis was that the short distance within-row spacing would gradually improve forage and seed yields.

\section{Materials and methods}

\section{Study site}

The field experiment was carried out at the Research Farm of the Faculty of Agriculture, Tarbiat Modares University, Tehran, Iran during 2000 spring. The site is located at $35^{\circ} 41^{\prime} \mathrm{N}$ latitude, $51^{\circ} 19^{\prime} \mathrm{E}$ longitude and altitudes of $1215 \mathrm{~m}$. Study site is located in about $17 \mathrm{~km}$ west of Tehran with a semi-arid climate. The yearly average precipitation (30-years long-term period) which is mostly concentrated during the autumn and winter months was $247 \mathrm{~mm}$.

\section{Soil sampling and analysis}

Before the beginning of experiment, soil samples were taken in order to determine the physical and chemical properties. A composite soil sample was collected at a depth of 0-30 cm. It was air dried, crushed, and tested for its physical and chemical properties. Total Kjeldahl nitrogen was determined using the standard digestion of Issac and Johnson (1976). Available P was determined by sodium bicarbonate $\left(\mathrm{NaHCO}_{3}\right)$ extraction and subsequent colorimetric analysis (Olsen et al., 1954). Available K was determined using an ammonium acetate extraction followed by emission spectrometry (Knudsen et al., 1982).
The soil of experimental site was sandy loam, low in nitrogen $(0.07 \%)$, low in organic matter (1.06) with a $\mathrm{pH}$ of 7.7. Details of soil properties are shown in Tab. 1 .

Tab. 1. Physical and chemical soil properties of experimental site

\begin{tabular}{cccccccc}
\hline \multirow{3}{*}{ Physical } & Depth & Sand & Silt & Clay & Texture & F.C & $\mathrm{B}_{\mathrm{d}}$ \\
\cline { 2 - 8 } & $\begin{array}{c}0-30 \\
\mathrm{~cm}\end{array}$ & $69 \%$ & $20 \%$ & $11 \%$ & $\begin{array}{c}\text { Sandy } \\
\text { loam }\end{array}$ & $\begin{array}{c}21 \% \\
\begin{array}{c}1.45 \\
\mathrm{~g} \mathrm{~cm}^{-2}\end{array}\end{array}$ \\
\hline \multirow{3}{*}{ Chemical } & Depth & $\mathrm{CEC}$ & $\mathrm{pH}$ & $\mathrm{O} . \mathrm{M}$ & $\mathrm{N}$ & $\mathrm{P}$ & $\mathrm{K}$ \\
\cline { 2 - 7 } & $\begin{array}{c}0-30 \\
\mathrm{~cm}\end{array}$ & $\begin{array}{c}4.6 \\
\mathrm{meq} / 100 \mathrm{~g}\end{array}$ & 7.7 & $1.06 \%$ & $0.07 \%$ & $\begin{array}{c}>12 \\
\mathrm{ppm}\end{array}$ & $\begin{array}{c}>350 \\
\mathrm{ppm}\end{array}$ \\
\hline
\end{tabular}

F.C: Field Capacity; $B_{d}$ : Bulk Density; CEC: Cation Exchange Capacity; O.M: Organic Matter; N: Total Nitrogen; P: Absorbable Phosphorous; $\mathrm{K}$ : : Absorbable Potassium

\section{The experimental design}

The experimental design was a randomized complete block arrangement in factorial with three replications. Treatments were arranged as $5 \times 3$ factorial combination of five annual medic species and three within-rows spacing $(20,30$, and $40 \mathrm{~cm})$. Each replication had 15 treatment combinations, which were randomized into plots.

\section{Field preparation and seed sowing}

The previous crop, before the study establishment, was corn. Field preparation was performed by plow and disk during the fall of the previous year. The plots were $1.2 \mathrm{~m}$ long and consisted of six rows, $0.4 \mathrm{~m}$ apart. Between all plots, $1 \mathrm{~m}$ alleys were kept. At late of winter of 2000 the seeds of five species of annual medics (Medicago scutellata cv. 'Sava'; M. littoralis cv. 'Herald'; M. polymorpha cv. 'Santiago'; M. minima cv. 'Orion' and M. truncatula cv. 'Mogul') were collected from Research Institute of Forests and Rangelands, Tehran, Iran (imported from Australia).

Hole-seeding was used, in which 5 to 8 seeds were hand planted at the depth of 1 to $2 \mathrm{~cm}$ at early of spring with 20 , 30 , and $40 \mathrm{~cm}$ within-rows and $40 \mathrm{~cm}$ between rows spacing. The plots were fertilized with $12.5 \mathrm{~kg} \mathrm{ha}^{-1}$ nitrogen in the form of urea immediately after planting as starter. The purpose of adding nitrogen fertilizer was to accelerate the growth of medic seedling and ensure the successful establishment of experimental field. Whereas, the soil of experiment site was wealthy of symbiotic bacteria three are no seed inoculation by Rhizobium trifolii. Irrigation was applied at weekly intervals. Weeds were controlled with hand hoeing as needed throughout the growing seasons. Primarily natural pollinators such as honeybees (Apis mellifera L.) provided pollination.

\section{Sampling and data collection}

Samples were hand harvested randomly by quadrate on a central area of $100 \times 100 \mathrm{~cm}$ within each sown plot at the end of the growth season and the following data were recorded; forage yield, seed yield, pod yield, number of pod in each plant, number of seed in pod, 1000 seed weight, seed to burr ratio, harvest index and hard seedness. 
118

To find out the number of pod in each plant, ten plants were selected randomly and numbers of pods were counted on each plant. The average of counted pods was used for statistical analysis. In order to determine the number of seeds in pods, 50 pods were selected randomly and then the number of seeds in each pod was counted. The average of counted seeds was used for statistical analysis. The 1000-seeds weight was determined from each plot. The seeds were counted by seed counter and then weighted at $13 \%$ standard moisture content. Seeds to burr ratio was calculated by harvesting of 100 pods randomly in each plot and separating of seeds from burrs and weighting as separately. Harvest index was calculated by weighting the seed yield and expressed as total biological yield. Shoots including leaves and stems were dried in oven at $60^{\circ} \mathrm{C}$ during 72 hours in order to calculate the dry biological yield. To determine changes in hard seedness after harvesting, pods were collected from the areas of each plot. Twentyfive seeds were removed randomly from each plot. After a brief storage in the laboratory, each sample was allocated into a petri dish and labeled. All petri dishes contained one piece of filter paper on the bottom and one piece of filter paper on the top of the seeds. Germination tests continued for 14 days in a humidified incubator at $25^{\circ} \mathrm{C}$. Germination determined the number and proportion of hard seeds.

\section{Statistical analysis of data}

All data were analyzed by analysis of variance (ANOVA) using the GLM procedure in SAS (SAS Institute, 2002). The assumptions of variance analysis were tested by insuring that the residuals were random, homogenous, with a normal distribution with a mean of zero. Duncan's Multiple Range tests were used to measure statistical differences between treatment methods and controls.

\section{Results and discussion}

Statistical probabilities of the $\mathrm{F}$ test for species and within-row spacing and their interactions for forage and seed yield, yield components, seed to burr ratio, harvest index and seed's hardness are summarized in Tab. 2. The results show that the interaction effect between species and within-row plant density was significant on forage yield, and M. polymorpha produces the highest forage yield $\left(2675.40 \mathrm{Kg} \mathrm{ha}^{-1}\right)$ when planted with the highest density. On the contrast, $M$. littoralis produces the least forage yield with the lowest density (Fig. 1). These differences might be caused by the genetically and environmentally characteristics. Increment of plant population improves net photosynthesis through increases the light's efficient use. High plant density improves forage yield in winter and as feed scarcity in winter imposes limits on year round animal production, high density can increase annual carrying capacity of pasture (Liaghat et al., 2008).

Main effects of within-row spacing, species and the interaction between them were significant on seed yield. The highest seed yield was obtained from M. polymorpha by $443.09 \mathrm{Kg} \mathrm{ha}^{-1}$ and $M$. Scutellata, by $409.99 \mathrm{Kg} \mathrm{ha}^{-1}$, respectively while, the least seed yield was observed on M. truncatula by $144.56 \mathrm{Kg} \mathrm{ha}^{-1}$ (Fig. 2). In addition, the highest seed yield ( $417.18 \mathrm{~kg} \cdot \mathrm{ha}^{-1}$ ) was produced in plots where seeds were sowed at a distance of $20 \mathrm{~cm}$ far from each other (Fig. 3). In general, the highest seed yield was achieved in high plant density namely $20 \mathrm{~cm}$ within-row spacing. It seems that there were not enough plants for the highest seed production in 30 and $40 \mathrm{~cm}$ distances apart (Fig. 3). Interaction between within-row spacing and species showed that, the highest and the lowest seed yield was attained on $M$. polymorpha with $20 \mathrm{~cm}$ distance and $M$. truncatulla and M. littoralis with $40 \mathrm{~cm}$ distance, respectively (Fig. 4). Different species used in the field experiments could cause such differences in seed yield. Seed yield of many species of annual medics increases until the optimum level by the increase of plant density, and afterwards decreases due to flower abscission. Results of Cazzato et al. (2000) amplify our results.

Within-row spacing and species have significant effect on pod yield since the highest pod yield was depended to M. scutellata; in contrast, the lowest pod yield was relative to $M$. truncatula and M. littoralis (Fig. 5). The results demonstrated that the highest pod yield was attained with 20 $\mathrm{cm}$ within-row or the highest plant density whereas equivalent with reduce of plant density pod yield was decreased (Fig. 6).

There were significant differences among species regarding the number of pods. The highest and the lowest pod number were getting from $M$. polymorpha and $M$.

Tab. 2. Statistical probabilities of $F$ test for main effects and their interactions on forage and seed yield, yield components, seed to burr ratio, harvest index and seed hardness

\begin{tabular}{ccccccccccc}
\hline S.O.V & D.F & $\begin{array}{c}\text { Forage } \\
\text { yield }\end{array}$ & $\begin{array}{c}\text { Seed } \\
\text { yield }\end{array}$ & $\begin{array}{c}\text { Pod } \\
\text { yield }\end{array}$ & $\begin{array}{c}\text { Pod number } \\
\text { in plant }\end{array}$ & $\begin{array}{c}1000 \text { seed } \\
\text { weight }\end{array}$ & $\begin{array}{c}\text { Seed number } \\
\text { in pod }\end{array}$ & $\begin{array}{c}\text { Seed to } \\
\text { burr ratio }\end{array}$ & $\begin{array}{c}\text { Harvest } \\
\text { index }\end{array}$ & $\begin{array}{c}\text { Seed } \\
\text { hardness }\end{array}$ \\
\hline Replication & 2 & $\mathrm{~ns}$ & $\mathrm{~ns}$ & $\mathrm{~ns}$ & $\mathrm{~ns}$ & $\mathrm{~ns}$ & $\mathrm{~ns}$ & $\mathrm{~ns}$ & $\mathrm{~ns}$ & $\mathrm{~ns}$ \\
Species & 4 & $\mathrm{~ns}$ & ${ }^{* *}$ & ${ }^{* *}$ & ${ }^{* *}$ & ${ }^{* *}$ & ${ }^{* *}$ & ${ }^{* *}$ & ${ }^{* *}$ & ${ }^{* *}$ \\
Within-row & 2 & $\mathrm{~ns}$ & ${ }^{* *}$ & ${ }^{* *}$ & ${ }^{* *}$ & $\mathrm{~ns}$ & $\mathrm{~ns}$ & $\mathrm{~ns}$ & $\mathrm{~ns}$ & $\mathrm{~ns}$ \\
\hline Species $\times$ within-row & 8 & ${ }^{* *}$ & ${ }^{* *}$ & $\mathrm{~ns}$ & ${ }^{* *}$ & $\mathrm{~ns}$ & $\mathrm{~ns}$ & $\mathrm{~ns}$ & $\mathrm{~ns}$ & $\mathrm{~ns}$ \\
\hline
\end{tabular}

${ }^{* *}$ Significant at the 0.01 probability level; NS, not significant 


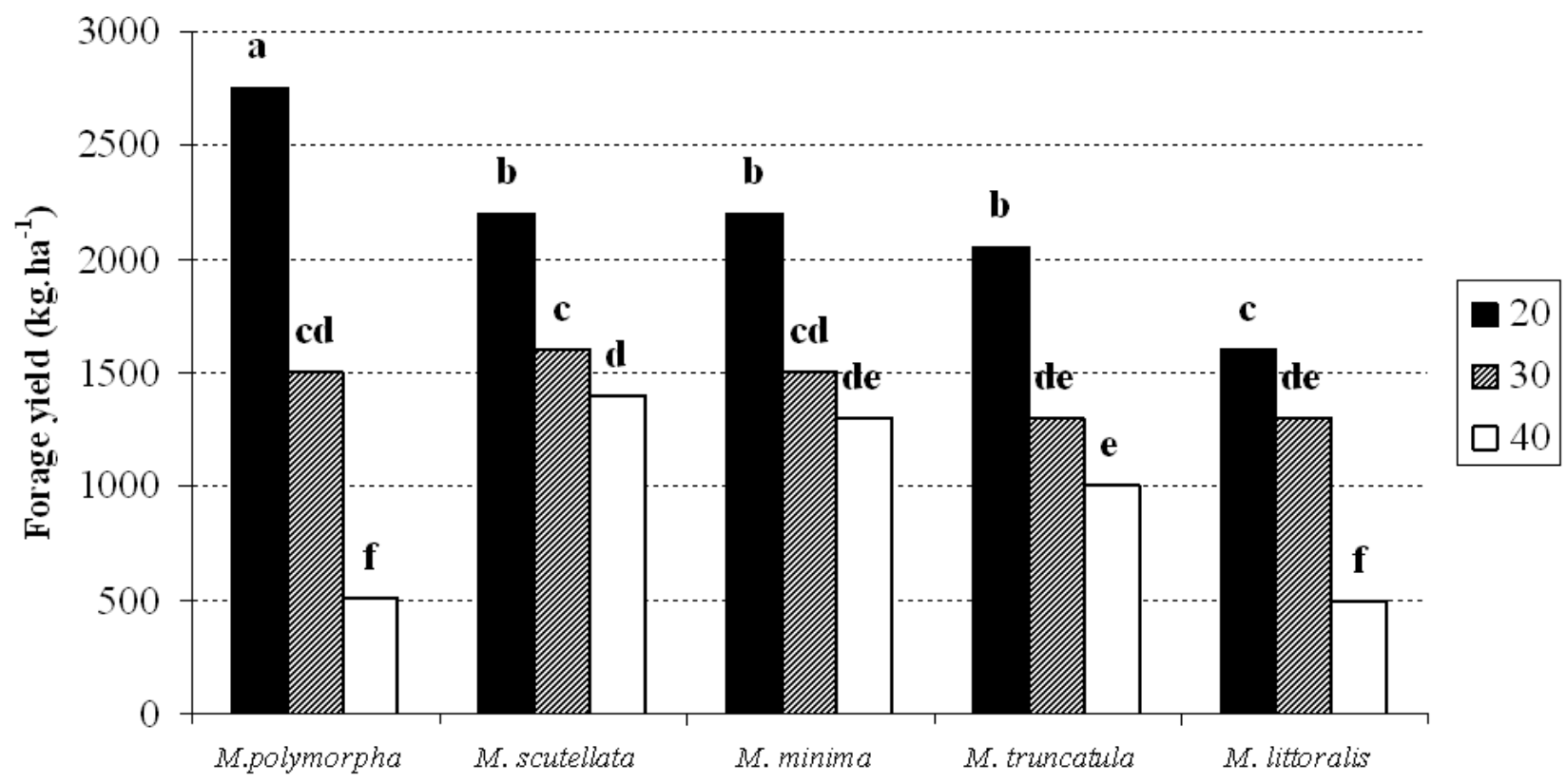

Species

Fig. 1. Interaction effect between species and within row spacing on forage yield. All the values followed by the same letter in each column are not statistically different at the $\mathrm{p}<0.05$ probability level

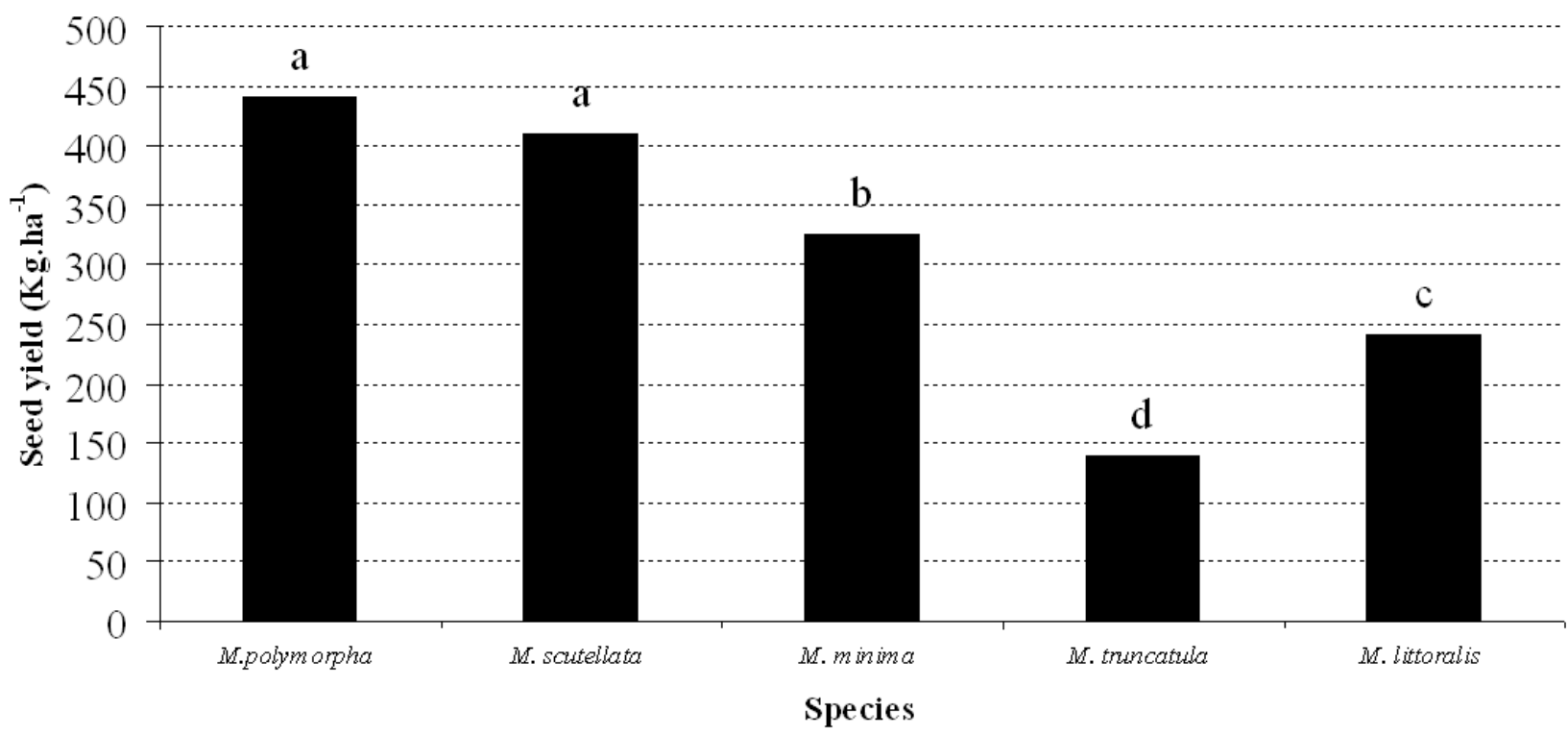

Fig. 2. Main effects of species on seed yield. All the values followed by the same letter in each column are not statistically different at the $\mathrm{p}<0.05$ probability level

scutellata, respectively (Fig. 7). In addition, effect of plant spacing was significant on pod number per plant. The highest and lowest pod number was obtained from 20 and $30 \mathrm{~cm}$ within-row spacing and $40 \mathrm{~cm}$ within-row spacing, respectively (Fig. 8). Interaction between the two factors showed significant differences on pod number in each plant. In $M$. polymorpha and $M$. littoralis reducing the distance to 20 and $30 \mathrm{~cm}$ between plants increased pod number than for $40 \mathrm{~cm}$ distance. In other species there was not significant differences among distances (Fig. 9). In many legumes, one of the effective factors on seed yield is pod number and commonly there is a linear function between pod number and seed yield. Cocks and Eheman (1987) reported that in all studied annual medics, seed yield was depended to pods number.

The M. scutellata and M. minima has the highest 1000 seeds weight while among other species there was no significant differences (Fig. 10). Meanwhile, within-row 


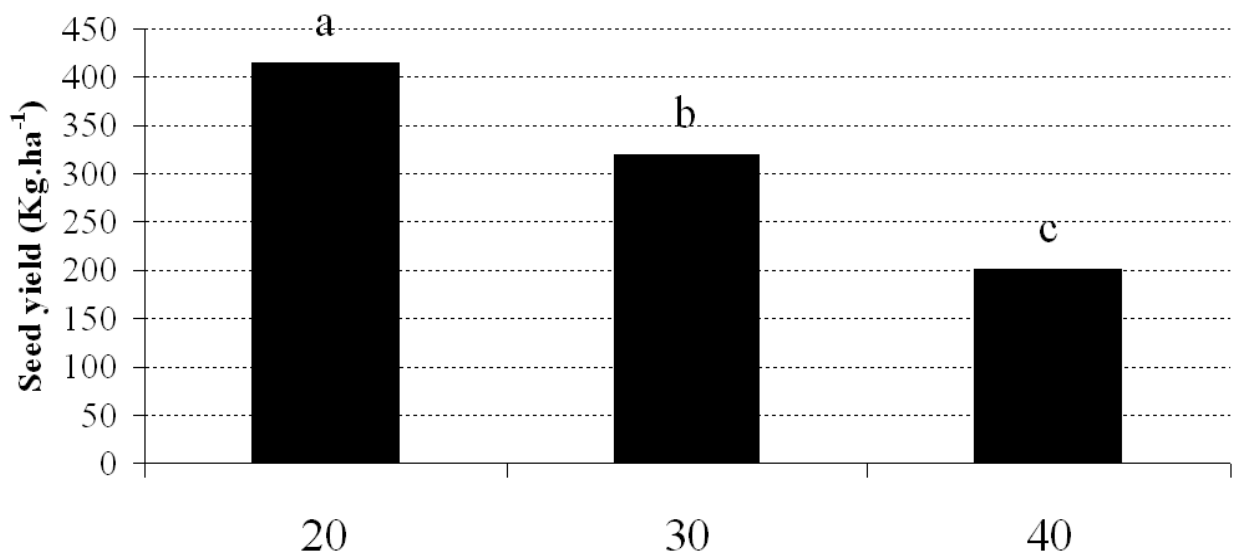

Distance on rows $(\mathrm{cm})$

Fig. 3. Main effects of within row spacing on seed yield. All the values followed by the same letter in each column are not statistically different at the $\mathrm{p}<0.05$ probability level

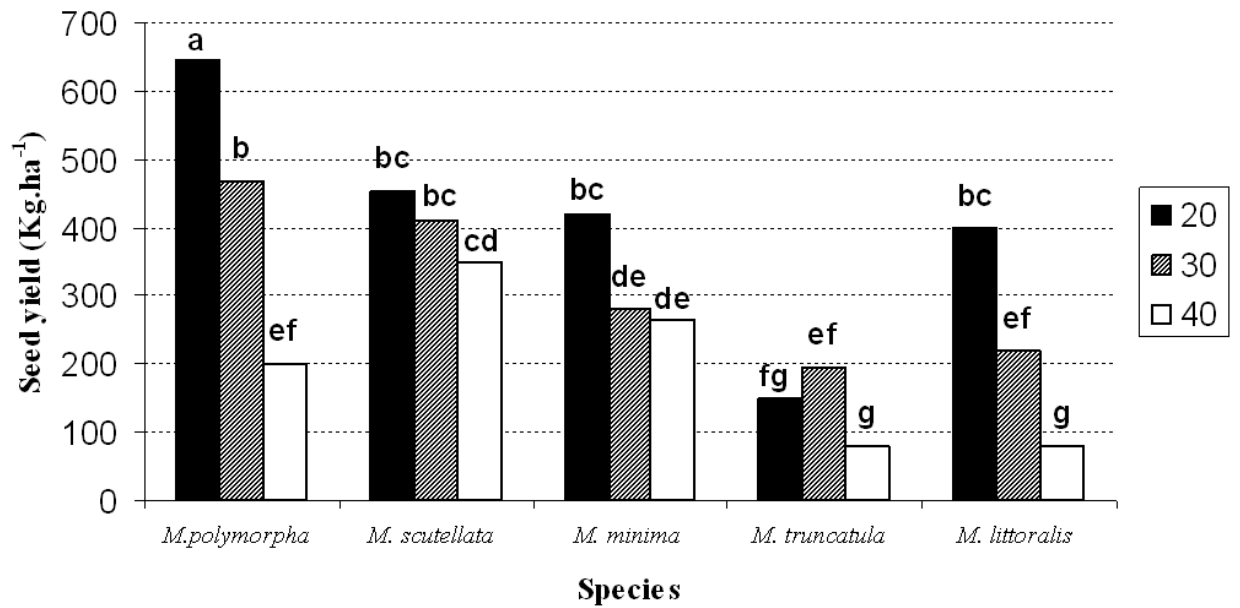

Fig. 4. Interaction effect between species and within row spacing on seed yield. All the values followed by the same letter in each column are not statistically different at the $\mathrm{p}<0.05$ probability level

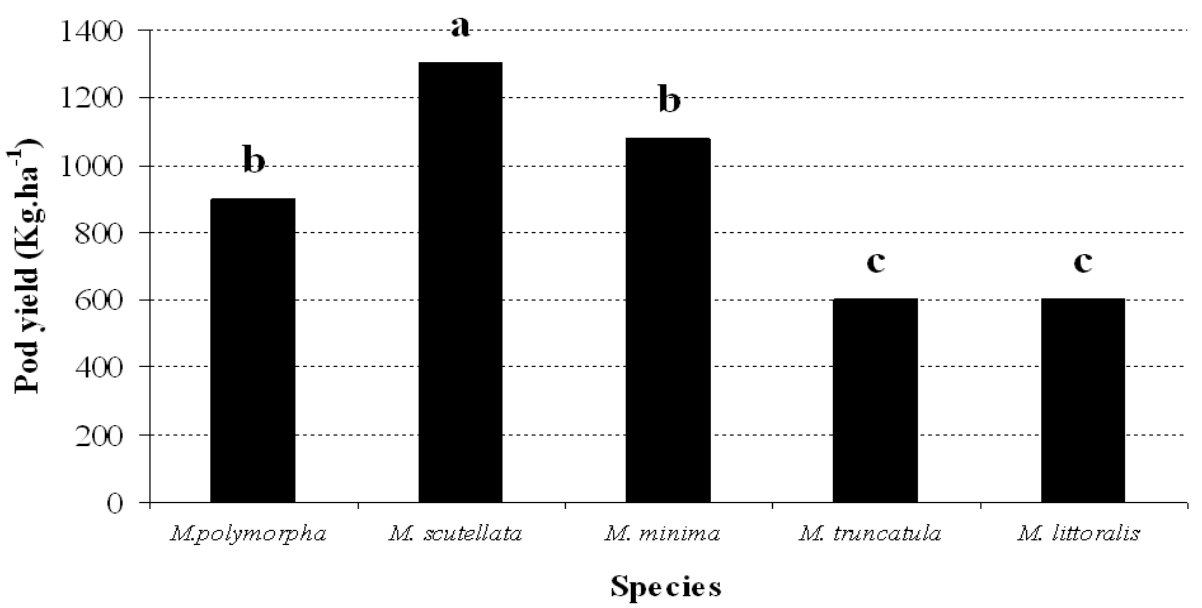

Fig. 5. Main effects of species on pod yield. All the values followed by the same letter in each column are not statistically different at the $\mathrm{p}<0.05$ probability level 


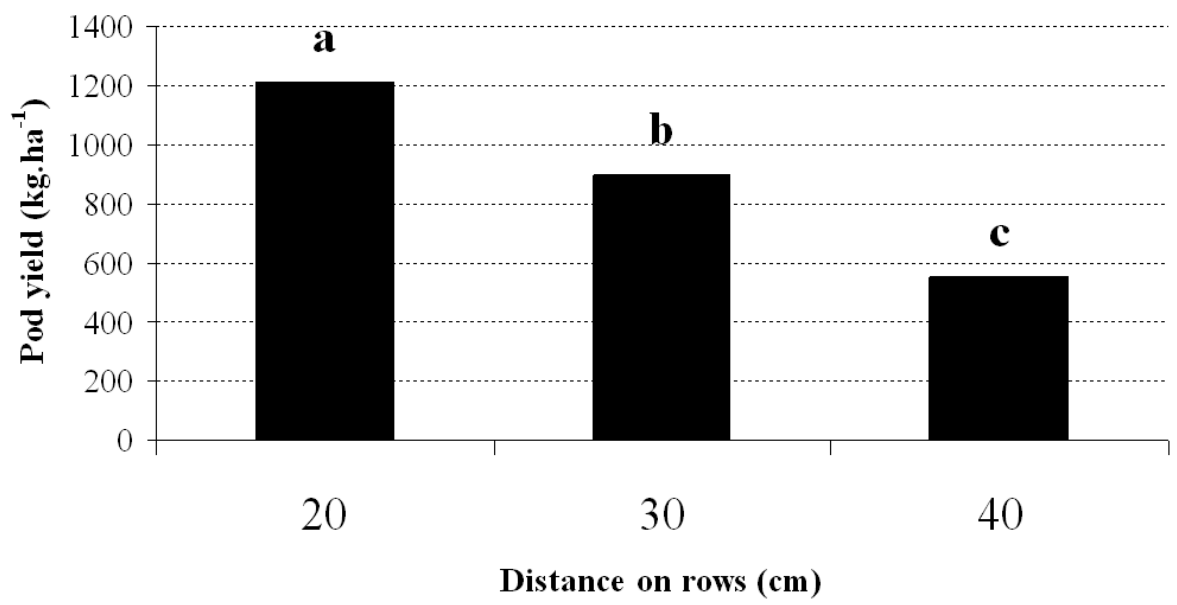

Fig. 6. Main effects of within row spacing on pod yield. All the values followed by the same letter in each column are not statistically different at the $\mathrm{p}<0.05$ probability level

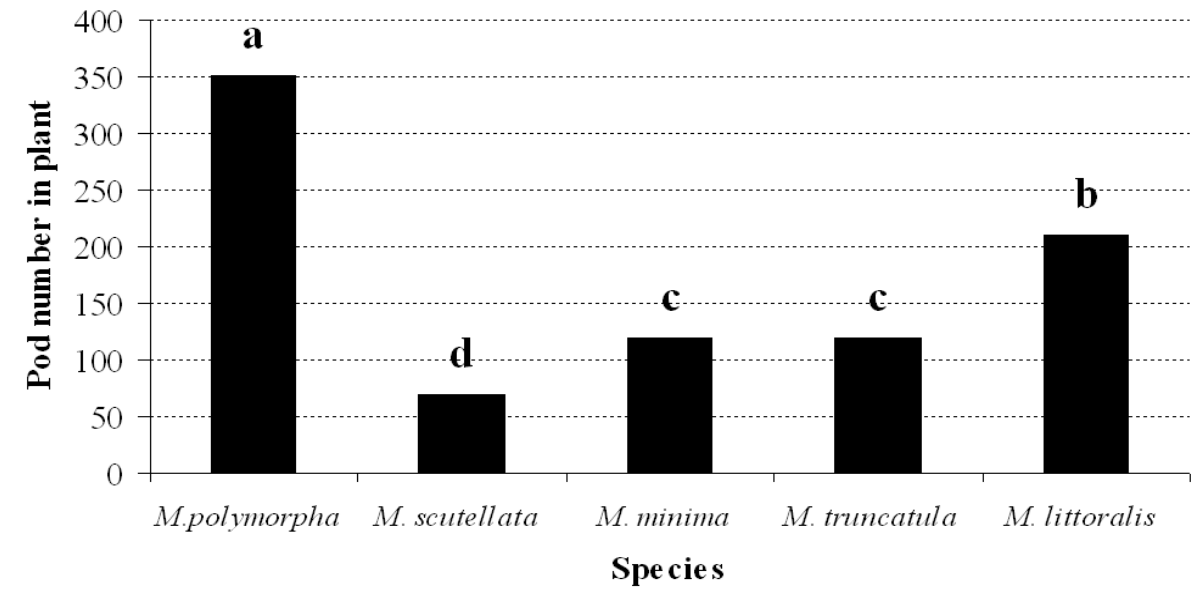

Fig. 7. Main effects of species on pod number in plant. All the values followed by the same letter in each column are not statistically different at the $\mathrm{p}<0.05$ probability level

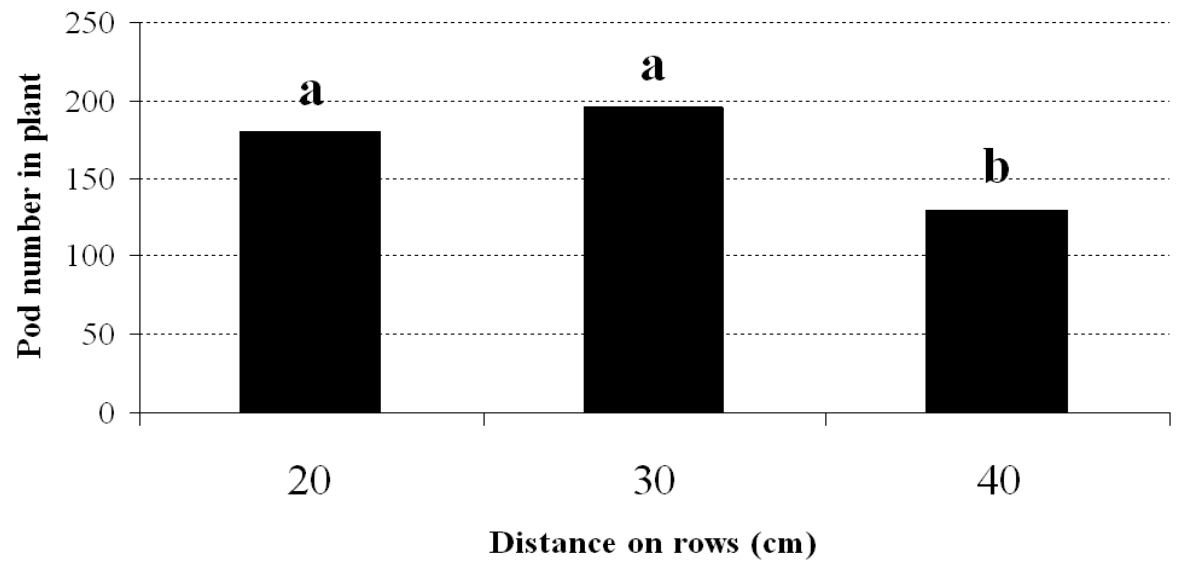

Fig. 8. Main effects of within row spacing on pod number in plant. All the values followed by the same letter in each column are not statistically different at the $\mathrm{p}<0.05$ probability level 


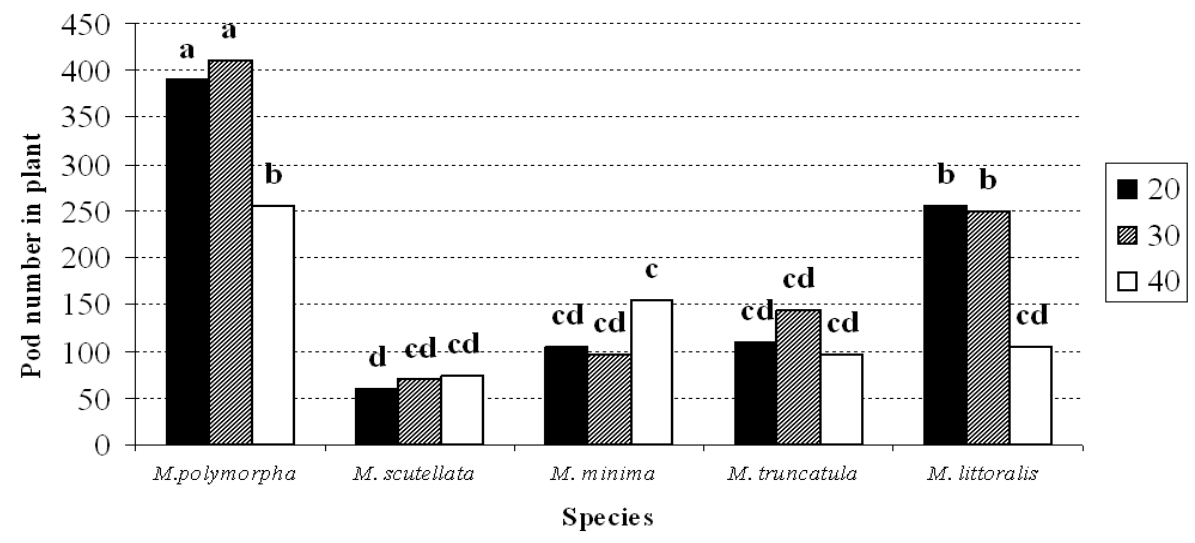

Fig. 9. Interaction effect between species and within row spacing on pod number in plant. All the values followed by the same letter in each column are not statistically different at the $\mathrm{p}<0.05$ probability level

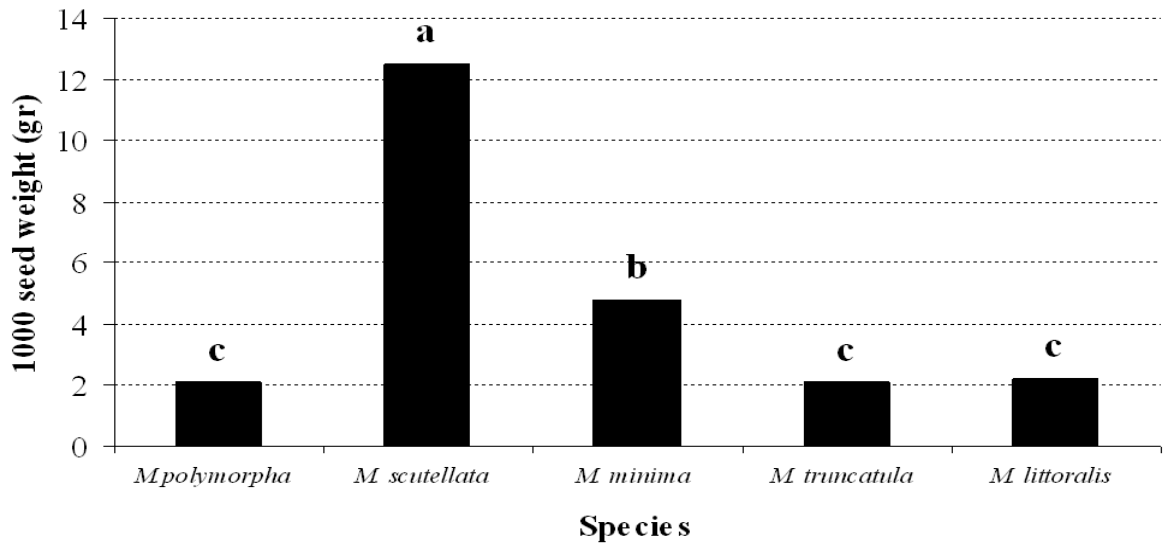

Fig. 10. Main effects of species on 1000 seed weight. All the values followed by the same letter in each column are not statistically different at the $\mathrm{p}<0.05$ probability level

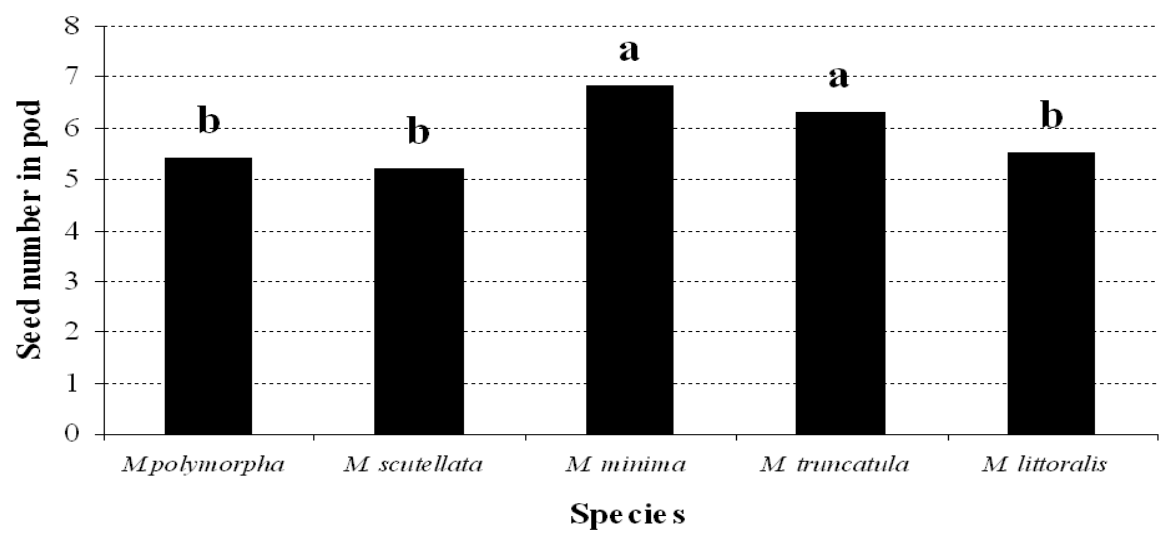

Fig. 11. Main effects of species on seed number in pod. All the values followed by the same letter in each column are not statistically different at the $\mathrm{p}<0.05$ probability level

spacing had no significant effect on 1000 seeds weight and also the interaction between species and density was no significant.

Seed number in pod was not affected by within-row spacing, moreover; the interaction between plant den- sity and species was not significant either. Comparison of means showed that M. minima and M. truncatulla have the highest seeds number per pod and other species were in later rank (Fig. 11). It seems that the number of seeds in annual medics is more stable than other yield component 


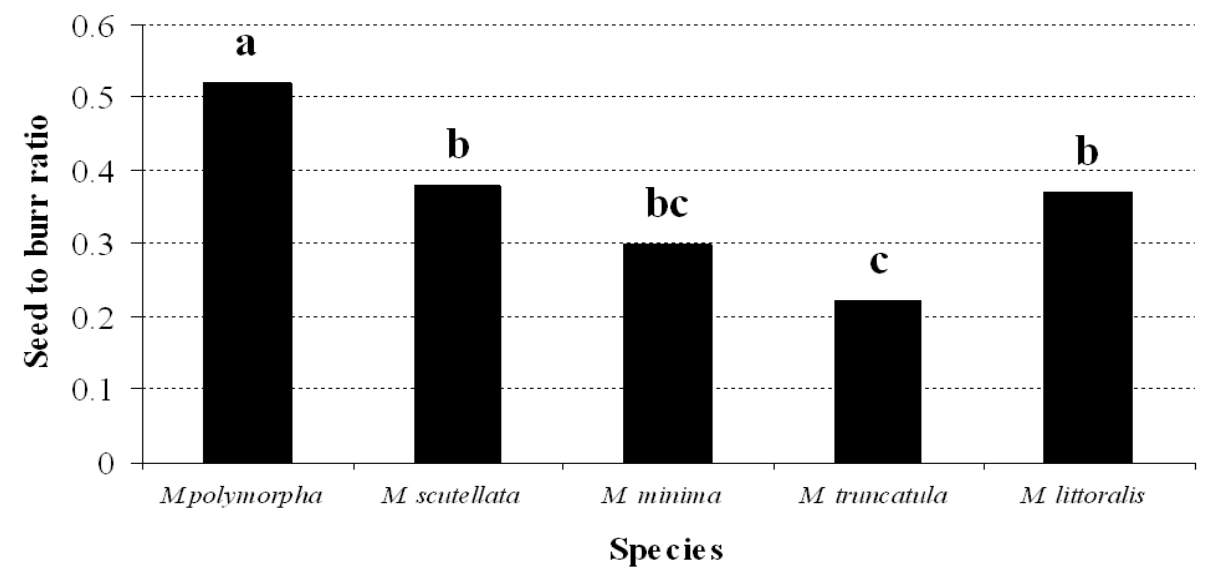

Fig. 12. Main effects of species on seed to burr ratio. All the values followed by the same letter in each column are not statistically different at the $\mathrm{p}<0.05$ probability level

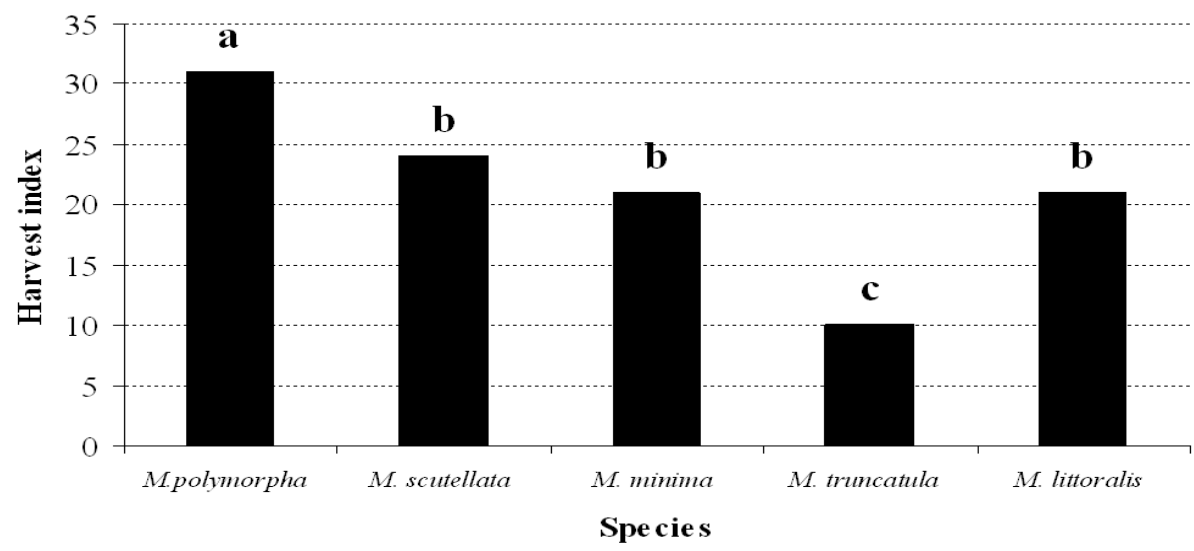

Fig. 13. Main effects of species on harvest index. All the values followed by the same letter in each column are not statistically different at the $\mathrm{p}<0.05$ probability level

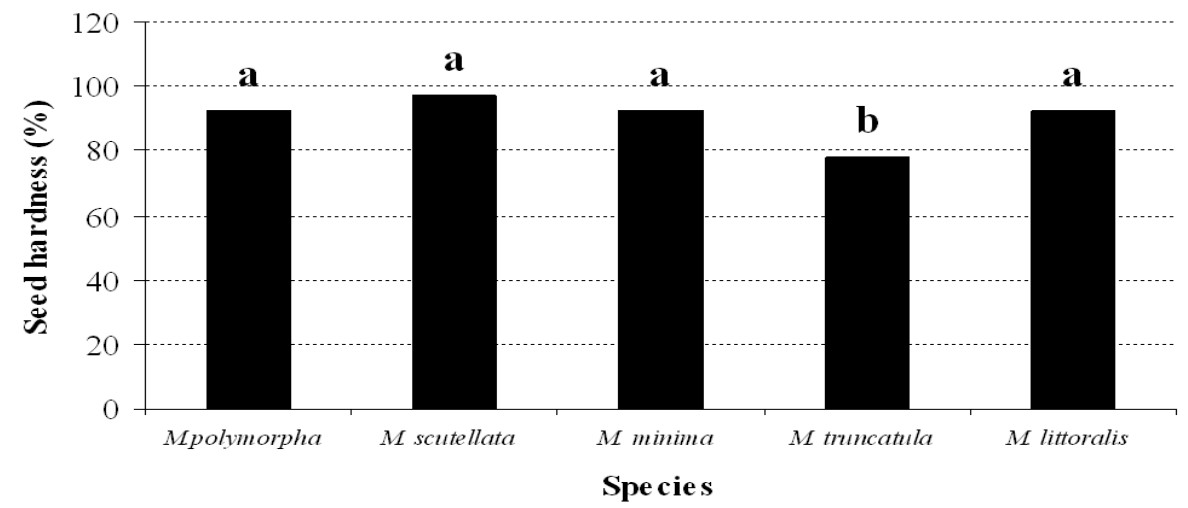

Fig. 14. Main effects of species on seed hardness. All the values followed by the same letter in each column are not statistically different at the $\mathrm{p}<0.05$ probability level

because ovules numbers are related to thegenetic of the species and are not affected by environmental conditions.

The results showed that different within-row spacing had not significant effect on burr to seed ratio while among species this difference was shown as M. polymorpha had the highest burr to seed ratio (Fig. 12).
It has reported that there are differences in burr to seed ratio in various annual medics (Crawford, 1971). There was a significant difference among studied annual medics on harvest index. Harvest index was not affected by the interaction between the mentioned factors. Whereas, harvest index depend on seed yield, an increase of seed yield leads to an increase of harvest index, therefore as according 
124

to this description the highest harvest index was obtained from M. polymorpha.

In this experiment, minimum hard seedness was obtained from M. truncatulla (Fig. 14). Impacts of withinrow and interaction effect were not significant on hard seedness. Hard seed ness in annual medics is an important mechanism which plays an especial role in seed's dormancy as it is the base of ley-farming system.

\section{Conclusions}

The results of this experiment showed that the maximum forage and seed yield were obtained from $M$. polymorpha with the highest plant density. This treatment is considered as the best treatment to forage and seed production.

\section{References}

Cazzato, E., A. Corleto and L. Sulas (2000). The effect of seeding rate and row spacing on seed yield and yield components of squarrosum clover and crimson clover in Southern Italy. Legumes for Mediterranean forage crops, pastures and alternative uses. Proceeding of the $10^{\text {th }}$ meeting of the Mediterranean Sub-Network of the FAO-CIHEAM InterRegional Cooperative Research and Development. Network on Pastures and Fodder Crops, Sassari, Italy, 4-9 April 2000, Cahiers-Options-Mediterraneennes 45:389-393.

Clarkson, N. M., N. P. Chaplain and M. L. Fairbairn (1987). Comparative effects of annual medics (Medicago spp.) and nitrogen fertilizer on the herbage yield and quality of subtropical grass pastures in southern inland Queensland. Aust. J. Exp. Agric. 27:257-265.

Cocks, P. S. and T. A. M. Eheman (1987). The geographic origin of frost tolerance in Syrian legumes. Journal of Applied Ecology 24:673-683.

Crawford,E.J.(1971).Seasonal changes in seed cost permeability of 155 lines of Medicago truncatula under field conditions. Australian seeds research conference, Canberra 1:14-15.

Crawford, E.J., A. W. H. Lake and K. G. Boyce (1989). Breeding annual Medicago species for semiarid conditions in southern Australia. Adv. Agron. 42:399-437.

Dordas, C. (2006). Foliar boron application improves seed set, seed yield, and seed quality of alfalfa. Agron. J. 98:907-913.

Gintzburger, G. (1994). Durabilite du developpement fourrager et pastoral et resources phytogenetiques en zones mediterraneennes Semi-Arides, 51-78 pp. In: Actes Seminaire Regional 19-20 Fevrier 1993. Meknes, Maroc, Tazi, M. and A. Ei Gharbaoui (Eds.). Reeseau Maghrebin des Parcours et Fourrages.
Hintz, R. W., K. A. Albrecht and E. S. Oplinger (1992). Yield and quality of soybean forage as affected by cultivar and management practices. Agron. J. 84:795-798.

Issac, R. A. and W. C. Johnson (1976). Determination of total nitrogen in plant tissue using a block digestor. J. Assoc. Off. Anal. Chem. 59:98-100.

Knudsen, D., G. A. Peterson and P. F. Pratt (1982). Lithium, sodium, and potassium, pp .225-246. In: A. L. Page et al. (Eds.). Methods of soil analysis: Part 2. $2^{\text {nd }}$ ed. SSSA Book Ser. 5. SSSA, Madison, WI.

Liaghat, A. R., M. R. Chaichi and M. B. Hosseini (2008). The Effect of Deferred Harvesting, Sowing Density and Harvest Intensity on Forage Yield, Seed Yield and Percent Hard-seedness of Annual Medic (Medicago scutelatta var. Robinson). American-Eurasian J. Agric. and Environ. Sci. 3:595-603.

Lloyd, D. L. and T. B. Hilder (1985). Dry matter production by a subtropical grass (Makarikari grass) grown in association with a temre annual legume (barrel medic) and nitrogen fertilizer in southern Queensland. Aust. J. Exp. Agric. 25:5460.

Olsen, S. R., C. V. Cole, F. S. Watanabe and L. A. Dean (1954). Estimation of available phosphorous in soils by extraction with sodium bicarbonate. USDA Circular 939. USDA, Washington, DC.

Pacucci, G., C. Troccoli, M. Falcinelli and D. Rosellini (1999). Agrotechnical factors and seed yield in common vetch (Visia sativa L.) in Southern Italy, 1. Effect of row spacing and sowing rates of vetch and barley. Herbage seed as a key factor for improving production and environmental quality. Proc. $4^{\text {th }}$ Int. herbage Seed Conference, Perugia, Italy, 23-27 May pp.83-87.

Puckridge, D. W. and R. J. French (1983). The annual legume pasture in cereal-ley farming systems of southern Australia: A review. Agric. Ecosyst. Environ. 9:229-267.

SAS Institute Inc. (2002). The SAS System for Windows, Release 9.0. Statistical Analysis Systems Institute, Cary, NC, USA.

Sheaffer, C. C., J. H. Orf, T. E. Devine and J. G. Jewett (2001). Yield and quality of foragesoybean. Agron. J. 93:99-106.

Spedding, C. R. W. (1971). Grassland Ecology. Oxford Univ., Press, Oxford pp.221.

Zhu, Y., C. C. Sheaffer and D. K. Barnes (1996). Forage yield and quality of six annual Medicago species in the northcentral USA. Agron. J. 88:955-960. 